\title{
Aplysia Synaptosomes. I. Preparation and Biochemical and Morphological Characterization of Subcellular Membrane Fractions
}

\author{
Gilbert J. Chin, Eli Shapiro, Steven S. Vogel, and James H. Schwartz \\ Howard Hughes Medical Institute, Center for Neurobiology and Behavior, Columbia University, \\ New York, New York 10032
}

\begin{abstract}
We prepared and characterized subcellular membrane fractions from the CNS of Aplysia californica that are enriched in isolated nerve terminals (synaptosomes). Ganglia were homogenized in $1.1 \mathrm{~m}$ sucrose and fractionated on a 2-step sucrose gradient, yielding $50 \mu \mathrm{g}$ protein/animal in the synaptosomal fraction (P3), which was enriched 3-fold in plasma membrane as compared with the initial homogenate. Quantitative morphometry of electron micrographs revealed that P3 contained $25 \%$ intact synaptosomes, a 5-fold enrichment over the homogenate. Although fractionation on a 5-step sucrose gradient reduced the yield of protein in the synaptosomal fraction to $\mathbf{4 0} \mu \mathrm{g} / \mathrm{animal}$, this fraction (the $0.35 \mathrm{~m}$ / $0.75 \mathrm{~m}$ interface) was more enriched in plasma membrane than P3 and was less contaminated by lysosomes and free mitochondria. By electron microscopy, the $0.35 \mathrm{~m} / 0.75 \mathrm{M}$ interface contained up to $50 \%$ synaptosomes. Synaptosomal fractions contained CAMP-, $\mathrm{Ca}^{2} /$ calmodulin-, and $\mathrm{Ca}^{2+} /$ phospholipid-dependent protein kinase activities and were enriched in a $M_{\mathrm{r}} \mathbf{4 0 , 0 0 0}$ pertussis toxin substrate, $G_{1 / 0}$. In the accompanying paper, we show that these synaptosomes retain the ability to release transmitters.
\end{abstract}

Synaptosomes are derived from nerve terminals that pinch off and reseal during homogenization (DeRobertis et al., 1962; Gray and Whittaker, 1962). Preparations from both vertebrate and invertcbrate ncrvous systems have been used for morphological, biochemical, and physiological studies of synaptic function (reviewed by Bradford, 1986). Synaptosomes can maintain a resting membrane potential, and they retain the ability to release transmitter in a $\mathrm{Ca}^{2+}$-dependent manner when exposed to elevated extracellular $\mathrm{K}^{+}$(DeBelleroche and Bradford, 1972; Blaustein, 1975). Transmitter release from active synaptosomes can be modulated by exogenously added physiological agents, such as ACh (DeBelleroche and Bradford, 1978), as well as by activators of protein kinases, such as phorbol esters (Nichols et al., 1987). Membrane fractions containing synaptic endings were used in earlier biochemical studies in Aplysia, but these were not extensively characterized (Eisenstadt and Schwartz, 1975; Eppler et al., 1982).

The cellular mechanisms underlying several kinds of synaptic

Received Oct. 23, 1987; revised May 26, 1988; accepted May 27, 1988.

We thank Alice Elste for electron microscopy, Robin Tewes for preparing figures, Jillayn Lindahl and Patricia Naughton for typing the manuscript, and Drs. Irving Kupfermann and Harvey Pollard for reading the manuscript critically.

Correspondence should be addressed to James H. Schwartz, M.D., Ph.D., Howard Hughes Medical Institute, Research Annex/Room 708, 722 West 168th Street, New York, NY 10032.

Copyright (C) 1989 Society for Neuroscience $0270-6474 / 89 / 010038-11 \$ 02.00 / 0$ modulation have been investigated in detail in the CNS of Aplysia (see, for example, Kandel and Schwartz, 1982). The heterosynaptic modulation of transmitter release has been shown to be mediated by second messengers that are generated or mobilized in response to presynaptic input (Kaczmarek and Levitan, 1987). In many instances, guanine nucleotide regulatory proteins have been implicated in the receptor-mediated production of second messengers (Gilman, 1987), and protein kinases found to be important targets for these signals (Nairn et al., 1985).

In this paper we describe the preparation of synaptosomes from Aplysia central ganglia by subcellular fractionation. We characterize the subcellular fractions biochemically and morphologically and determine the distribution of enzymes that participate in the metabolism of second messengers. In the accompanying paper we show that these synaptosomes are physiologically active and describe transmitter release from Aplysia synaptosomes and its modulation by histamine.

\section{Materials and Methods}

Aplysia (75-200 gm) were obtained from Marinus (Sand City, CA) or from the Howard Hughes Medical Institute's Mariculture Facility at the Woods Hole Oceanographic Institution. Radiochemicals were purchased from New England Nuclear (Boston). Biochemicals were from Sigma (St. Louis) unless otherwise specified.

Preparation of synaptosomes. The structure and dissection of the Aplysia CNS have becn described (Schwartz and Swanson, 1987). $\mathrm{Ca}^{2+}-$ free normal seawater (NSW-Ca ${ }^{2+}$ ) contained $460 \mathrm{~mm} \mathrm{NaCl}, 10 \mathrm{~mm} \mathrm{KCl}, 55$ $\mathrm{mm} \mathrm{MgCl}, 20 \mathrm{~mm}$ Tris- $\mathrm{HCl}$ ( $\mathrm{pH} 7.4$ ), and $0.1 \%$ glucose.

Typically, synaptosomes were prepared from the CNS of 4 animals. Ganglia (abdominal, buccal, cerebral, pedal, and pleural) were trimmed of extraneous connective tissue sheath and blotted to remove seawater. All procedures then were carried out at $4^{\circ} \mathrm{C}$. The ganglia were homogenized by hand in $0.75 \mathrm{ml} 1.1 \mathrm{M}$ sucrose, $25 \mathrm{~mm}$ Tris- $\mathrm{HCl}$ (pH 7.4) with a Duall ground glass tissue grinder (size 20, Kontes, Vineland, NJ). The thick sheath in animals heavier than $200 \mathrm{gm}$ interfered with homogenization. Large pieces of sheath were removed by hand, and the remainder of the homogenate $(\mathrm{H})$ was transferred to a $15 \mathrm{ml}$ plastic, conical tube.

In the 2-step protocol (Fig. 1), a density gradient was constructed by laycring $0.75 \mathrm{ml} 0.8 \mathrm{M}$ sucrose, $25 \mathrm{~mm}$ Tris- $\mathrm{HCl}(\mathrm{pH} \mathrm{7.4)}$ over the homogenate. Centrifugation in a table-top centrifuge $(1625 \times \mathrm{g})$ for 10 min yielded a pellet (P1), a deep orange lower layer, and a light orange upper layer. The 2 sucrose layers were each diluted with 3 vol of NSW$\mathrm{Ca}^{2+}$ and centrifuged in an Eppendorf microfuge $(15,600 \times g)$ for $8 \mathrm{~min}$, producing pellets (P2 and P3) and supernatants (S2 and S3) from the lower and upper layers. P2 and P3 were resuspended in $0.1-0.2 \mathrm{ml}$ NSW- $\mathrm{Ca}^{2+}$.

In the 5-step protocol (Fig. 1), a low-speed supernatant (S1) was prepared by table-top centrifugation $(1625 \times g)$ of the homogenate for $10 \mathrm{~min}$. The sucrose gradients consisted of the following solutions (all buffered with $25 \mathrm{mM}$ Tris- $\mathrm{HCl}, \mathrm{pH} 7.4): 1.5 \mathrm{M}$ sucrose $(0.4 \mathrm{ml}), 1.1 \mathrm{M}$ sucrose $(0.4 \mathrm{ml}), \mathrm{S} 1(0.7 \mathrm{ml}), 0.75 \mathrm{M}$ sucrose $/ 0.15 \mathrm{M} \mathrm{NaCl}(2.0 \mathrm{ml})$, and $0.35 \mathrm{M}$ sucrose $/ 0.35 \mathrm{M} \mathrm{NaCl}(0.5 \mathrm{ml})$; these were centrifuged in an SW60 
rotor at $19,300 \mathrm{rpm}(50,000 \times g)$ for $20 \mathrm{~min}$. The 4 interfaces and the original S1 layer (approximately $0.9 \mathrm{M}$ in sucrose) were collected, diluted 3 -fold with NSW-Ca ${ }^{2+}$, and centrifuged in a microfuge $(15,600 \times g)$ for $10 \mathrm{~min}$. The pellets were resuspended in $0.1 \mathrm{ml} \mathrm{NSW}-\mathrm{Ca}^{2+}$. For comparison, a similar pellet $\left(\mathrm{P}_{\mathrm{SI}}\right)$ was prepared from a portion of $\mathrm{S1}$.

Using the criterion of the ability to release transmitter (Chin et al., 1989), we found that homogenization buffers of normal ionic strength $(460 \mathrm{~mm} \mathrm{NaCl})$ or lower osmolarity $(0.8 \mathrm{M}$ sucrose) did not work as well as $1.1 \mathrm{M}$ sucrose and that inclusion of protease inhibitors (EGTA, benzamidine, aprotinin) did not improve the recovery. If neural components were first prepared by removing the sheath from ganglia by dissection, no activity was recovered, probably because the isolated components were degraded in the time needed to collect sufficient amounts of tissue (there is less than $1 \mathrm{mg}$ of neural component protein per animal). The rapid decay of transmitter releasing activity (undetectable after $1 \mathrm{~d}$ ) and the coacervation of Aplysia membranes in NSW$\mathrm{Ca}^{2+}$ (Eisenstadt and Schwartz, 1975) hindered our efforts at further purification. Pollard and Pappas (1979) prepared squid synaptosomes by homogenization and flotation in $1.0 \mathrm{M}$ sucrose.

Assays for marker enzymes. Assays were conducted at $23^{\circ} \mathrm{C}$ and were linear with time and with amount of tissue. Protein was measured (Lowry et al., 1951) in the presence of 1.0\% SDS using BSA standards prepared in the appropriate buffers. $5^{\prime}-$ Nucleotidase was assayed by the liberation of ${ }^{3} \mathrm{H}$-adenosine from ${ }^{3} \mathrm{H}$-AMP (Avruch and Wallach, 1971).

Acid phosphatase was assayed by following the appearance of the $p$-nitrophenol anion. Activity was measured in $0.4 \mathrm{ml}$ of $0.25 \mathrm{M} \mathrm{Na}$ acetate (pH 5.0), $5 \mathrm{~mm}$ p-nitrophenyl phosphate, and $0.1 \%$ Triton $X$ 100. After $45 \mathrm{~min}, 0.4 \mathrm{ml}$ of $1 \mathrm{~N} \mathrm{NaOH}$ was added to stop the reaction, and the absorbance was measured at $410 \mathrm{~nm}$ using an extinction coefficient of $1.8 \times 10^{4} \mathrm{M}^{-1} \mathrm{~cm}^{-1}$. Cytochrome $\mathrm{c}$ oxidase was assayed spectrophotometrically in $1.0 \mathrm{ml}$ of $50 \mathrm{mM} \mathrm{KH}_{2} \mathrm{PO}_{4}(\mathrm{pH} 7.5)$ containing 1 $\mathrm{mg} / \mathrm{ml}$ horse heart cytochrome $\mathrm{c}$ (reduced, orange), prepared by adding a pinch of sodium dithionite to a $10 \mathrm{mg} / \mathrm{ml}$ stock solution of cytochrome $c$ (oxidized, deep red). The rate of change in absorbance was measured at $550 \mathrm{~nm}$ using an experimentally determined extinction coefficient of $1.88 \times 10^{4} \mathrm{M}^{-1} \mathrm{~cm}^{-1}$ for the difference in absorbance between the oxidized and reduced forms.

Electron microscopy. We used morphometric analysis of electron micrographs (Williams, 1977) to evaluate the distribution of isolated nerve endings in synaptosomal fractions and to compare different methods for preparing synaptosomes.

Membrane fractions P2 and P3 were prepared using a 2-step gradient (Fig. 1). Samples of the homogenate and P1 pellet were diluted in NSW$\mathrm{Ca}^{2+}$ and centrifuged in a microfuge for $10 \mathrm{~min}$. The resulting pellets $(\mathrm{H}, \mathrm{P} 1, \mathrm{P} 2$, and $\mathrm{P} 3)$ were fixed in $5 \%$ glutaraldehyde, postfixed in $1 \%$ $\mathrm{OsO}_{4}$, and prepared for electron microscopy (Thompson et al., 1976). The microfuge pellets derived from the interfaces of the 5-step gradient (Fig. 1) were fixed and processed similarly.

To evaluate the areas occupied by various membrane profiles, we used point counting analysis (Williams, 1977). Thin sections (80-100 $\mathrm{nm}$ ) were stained with uranyl acetate and lead citrate, and examined and photographed in a Phillips $301 \mathrm{EM}$. A series of 10-15 micrographs at a magnification of 19,170 in columns from top to bottom through the pellet was used in order to take into account the heterogeneity of the pellets. Each micrograph was placed under a rectangular point grid, and the membrane compartments under each point were scored as synaptosomes, mitochondria, lysosomes, or as other membrane (which included chromatin, small vesicles, connective tissue, unidentified membrane, and glial cell areas). The criterion used to identify synaptosomal membrane was an area containing synaptic vesicles encircled by plasma membrane. This criterion was applied rigorously so that representative micrographs, all of which were taken from the bottom third of the pellets (Figs. 2-4), may appear more enriched than the point counting analysis indicates (Table 3). Many, but not all, synaptosomes contained enclosed mitochondria. The diameter of structures counted as synaptosomal ranged from 0.4 to $4.0 \mu \mathrm{m}$, and the number of enclosed synaptic vesicles was variable.

In pilot comparisons of preparative procedures, one series of micrographs was examined for each fraction using a 54-point grid yielding about 500 points/fraction. Two preparations using homogenization in $0.8 \mathrm{M}$ sucrose and 2 preparations using homogenization in $1.1 \mathrm{M}$ sucrose were analyzed. Homogenization in $1.1 \mathrm{M}$ sucrose gave better preservation of tissue and a higher proportion of isolated nerve terminal membrane in the synaptosomal fraction, P3. For the more detailed analyses, 3 series of micrographs from each pellet were examined using a 108-point grid, an average of 4100 points/fraction. The relative stan-
TWO-STEP GRADIENT

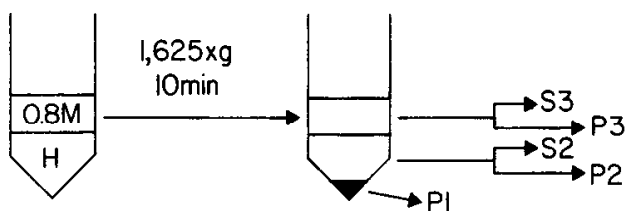

\section{FIVE-STEP GRADIENT}

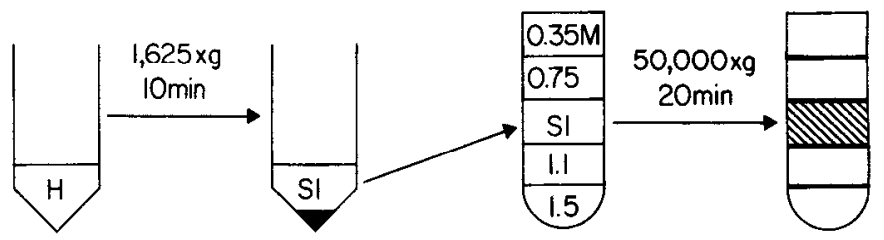

Figure 1. Subcellular fractionation of Aplysia nervous tissue on discontinuous sucrose gradient. The upper and lower sucrose layers from the 2-step gradient were diluted with 3 vol of NSW-Ca ${ }^{2+}$ and centrifuged in a microfuge. The supernatants were designated $S 3$ and $S 2$, the pellets, $\mathrm{P} 3$ and $\mathrm{P} 2$. From the 5-step gradient, membrane fractions were prepared by diluting the 4 interfaces and the $\mathrm{S} 1$ sucrose layer with $\mathrm{NSW}-\mathrm{Ca}^{2+}$ and pelleting in a microfuge.

dard error (Williams, 1977) of the measurement of synaptosomal content was less than $10 \%$ for all 4 fractions.

Assays of protein kinases. Three types of kinase activities were measured. All assays were performed at $23^{\circ} \mathrm{C}$ in $50 \mathrm{~mm} \mathrm{3-}(\mathrm{N}$-morpholino)propanesulfonic acid (pH 7.0 with $\mathrm{NaOH}$ ), $20 \mathrm{~mm} \mathrm{MgCl}_{2}, 1 \mathrm{~mm}$ dithiothreitol, $0.1 \mathrm{mg} / \mathrm{ml}$ BSA (fatty acid-free) with additions as noted. Samples $(1-5 \mu \mathrm{g}$ protein in $0.1 \mathrm{ml})$ were first incubated for $10 \mathrm{~min}$ at $23^{\circ} \mathrm{C}$; reactions were initiated by adding $\gamma-{ }^{32} \mathrm{P}-\mathrm{ATP}(200 \mathrm{Ci} / \mathrm{mol})$. Samples of $40 \mu \mathrm{l}$ were removed at 5 and $10 \mathrm{~min}$, and spotted on $2.4 \mathrm{~cm}$ disks of P81 filter paper (Whatman, Hillsboro, OR), which were washed 4 times with $75 \mathrm{mM} \mathrm{H}_{3} \mathrm{PO}_{4}$ prior to scintillation counting (Roskoski, 1983). The kinase reactions were linear with time for all of the subcellular fractions. Linearity with sample protein added was determined using dilutions of the homogenate.

cAMP-dependent protein kinase activity was defined as incorporation of radioactivity that was dependent on the presence of the heptapeptide substrate, LRRASLG (Eppler et al., 1986); this was essentially equivalent to the incorporation that was dependent on the presence of $10 \mu \mathrm{M}$ cAMP. Under these conditions we found that greater than $97 \%$ of the ${ }^{32} \mathrm{P}$ incorporation was phosphorylation of the peptide, and $90 \%$ of the phosphorylation was inhibited at $100 \mu \mathrm{g} / \mathrm{ml}$ protein kinase inhibitor (Sigma).

$\mathrm{Ca}^{2+} /$ calmodulin-dependent protein kinase activity is defined as incorporation of radioactivity that was dependent on the presence of both $\mathrm{Ca}^{2+}$ (versus EGTA) and the synthetic peptide substrate corresponding to residues 11-23 of chicken gizzard smooth muscle myosin light chain (Peninsula, Belmont, CA) (Kemp et al., 1983). Calmodulin-dependent protein kinase was assayed using the peptide at $50 \mu \mathrm{M}$ in the presence of $20 \mu \mathrm{g} / \mathrm{ml}$ bovine brain calmodulin, $100 \mu \mathrm{g} / \mathrm{ml}$ protein kinase inhibitor, $0.5 \mathrm{mM} \mathrm{CaCl}_{2}, 0.1 \%$ Nonidet P-40 (NP-40), and $50 \mu \mathrm{M}$ ATP. Under these conditions, the $\mathrm{Ca}^{2+}$-dependent phosphorylation of the peptide accounted for all of the ${ }^{32} \mathbf{P}$ incorporated. This $\mathrm{Ca}^{2+}$-dependent phosphorylation was taken to be calmodulin-dependent kinase activity because it was stimulated $25-50 \%$ by exogenous calmodulin and inhibited $85 \%$ by $50 \mu \mathrm{M}$ trifluoroperazine. This activity is unlikely to be due to protein kinase $\mathrm{C}$ (fragment $\mathrm{M}$ of protein kinase $\mathrm{C}$ is $\mathrm{Ca}^{2+}$-independent) because this peptide is not phosphorylated by purified mouse protein kinase $C$ in the absence of phosphatidyl serine (Hassell et al., 1986), and Aplysia protein kinase $\mathrm{C}$ is strongly dependent on phosphatidyl serine (see below). Nevertheless, definitive resolution of this point awaits purification of these kinases from Aplysia.

Protein kinase $C$ activity was defined as incorporation of radioactivity that is dependent on the presence of both phosphatidyl serine and phor- 
Table 1. Distribution of membrane marker enzymes in the 2-step gradient

\begin{tabular}{llllr} 
Fraction & $\begin{array}{l}\text { Protein } \\
(\mathrm{mg} / \text { animal) }\end{array}$ & $\begin{array}{l}5^{\prime} \text {-Nucleotidase } \\
(\mathrm{pmol} / \mathrm{min} / \mathrm{mg})\end{array}$ & $\begin{array}{l}\text { Acid phosphatase } \\
(\mathrm{nmol} / \mathrm{min} / \mathrm{mg})\end{array}$ & $\begin{array}{l}\text { Cytochrome } \\
\text { c oxidase } \\
(\mathrm{nmol} / \mathrm{min} / \mathrm{mg})\end{array}$ \\
\hline H & $1.04 \pm 0.07(100)$ & $102 \pm 11(100)$ & $67.6 \pm 6.6(100)$ & $59.8 \pm 21.2(100)$ \\
P1 & $0.36 \pm 0.03(34.6)$ & $113 \pm 9(42.4)$ & $87.7 \pm 1.5(46.7)$ & $73.5 \pm 24.1(50.2)$ \\
P2 & $0.11 \pm 0.01(10.6)$ & $293 \pm 48(30.0)$ & $97.5 \pm 5.0(16.3)$ & $151.2 \pm 45.8(29.2)$ \\
P3 & $0.05 \pm 0.01(4.8)$ & $277 \pm 28(13.3)$ & $75.8 \pm 8.3(5.3)$ & $60.4 \pm 21.0(6.4)$ \\
S2 & $0.38 \pm 0.03(36.5)$ & $60 \pm 4(22.1)$ & $30.5 \pm 5.1(16.2)$ & $6.5 \pm 4.1(2.7)$ \\
S3 & $0.13 \pm 0.03(12.5)$ & $95 \pm 13(14.2)$ & $27.9 \pm 7.6(6.1)$ & $10.2 \pm 6.4(1.3)$ \\
Recovery & $(99.0)$ & $(122)$ & $(90.6)$ & $(89.8)$ \\
\hline
\end{tabular}

An Aplysia nervous tissue homogenate was fractionated on a 2-step sucrose gradient (Fig. 1), and enzyme activities were measured as described in Materials and Methods. Results of 4 independent preparations are presented as $\bar{x} \pm$ SEM with percentage yields and the recovery of homogenate activity in the fractions in parentheses.

bol cstcr. Protcin kinase $\mathrm{C}$ was assayed using histone H1 (Sigma typc IIIS) at $0.4 \mathrm{mg} / \mathrm{ml}$ in the presence of $100 \mu \mathrm{g} / \mathrm{ml}$ protein kinase inhibitor, $200 \mathrm{~nm}$ phorbol 12 -myristate 13 -acetate, $150 \mu \mathrm{g} / \mathrm{ml}$ phosphatidyl serine, and $50 \mu \mathrm{M}$ ATP (Sacktor et al., 1986). Under these conditions, the phosphatidyl serine/phorbol ester-dependent phosphorylation was confined to histone and was $82 \%$ of the total ${ }^{32} \mathrm{P}$ incorporation.

${ }^{32} P$-ADP-ribosylation. Subcellular fractions and homogenates were labeled with ${ }^{32}$ P-NAD and pertussis toxin as described (Vogel et al., 1989), and analyzed by SDS gel electrophoresis. Additions to the reaction mixture are detailed in the figure legend. Incorporation was quantitated by solubilizing the gel slices (Chin, 1985) for scintillation counting.

\section{Results}

Aplysia nervous tissue was homogenized and fractionated on either a 2-step or 5-step discontinuous sucrose gradient (Fig. 1). We used the 2-step gradient protocol for most of the experiments presented in this and the following paper because it was developed first and produced a partially purified synaptosome fraction, P3, within $1 \mathrm{hr}$ after dissection of the animals. The 5-step gradient protocol was developed much later, took more time to carry out, and produced a synaptosomal fraction, the $0.35 \mathrm{M} / 0.75$ $\mathbf{M}$ interface, of greater purity but of lower protein yield.

We first determined biochemically the distribution of plasma membrane, lysosomes, and mitochondria in the gradients. The particulate fractions were then examined in the EM and quantitatively analyzed for synaptosomes, lysosomes, and mitochondria. We also measured synaptosomal protein kinases and $\mathrm{G}$ proteins.

\section{Distribution of membranes}

The distribution of membrane components in the gradient fractions was determined by measuring the activities of marker enzymes. 5'-Nucleotidase was used as a marker for plasma membranes, acid phosphatase for lysosomes, and cytochrome $c$ oxidase for mitochondria. We could not reliably detect either glucose-6-phosphatase (a marker for the endoplasmic reticulum) or UDP-galactose: $N$-acetylglucosamine galactosyl transferase (the Golgi complex) in any of the subcellular fractions.

The membrane fractions, P2 and P3, from the 2-step sucrose gradient were enriched in all 3 marker enzymes (Table 1) as compared with the homogenate. P2 and P3 were not identical in their membrane content, however. While the specific activity of 5 -nucleotidase was about the same in P2 and P3, in P3 the specific activities of acid phosphatase and cytochrome c oxidase were lower. The supernatant fractions, S2 and S3, with about half of the total homogenate protein, had lower specific activities of 5'-nucleotidase, acid phosphatase, and cytochrome c oxidase than did the homogenate, indicating that they were not enriched in plasma membrane, lysosomes, or mitochondria.

The 5-step gradient produced a greater enrichment of plasma membranes ( $5^{\prime}$-nucleotidase specific activity) than did the 2-step gradient, and contamination from lysosomes and mitochondria was reduced (Table 2). The yield of protein in the $0.35 \mathrm{M} / 0.75$ M interface fraction, $40 \mu \mathrm{g} /$ animal, was slightly less than in P3 (50 $\mu \mathrm{g}$ /animal). Acid phosphatase activity was highest at the 0.9

Table 2. Distribution of membrane marker enzymes in the 5-step gradient

\begin{tabular}{|c|c|c|c|c|c|c|}
\hline \multirow[b]{2}{*}{ Fraction } & \multirow{2}{*}{$\begin{array}{l}\text { Protein } \\
\text { ( } \mu \mathrm{g} / \text { animal })\end{array}$} & \multirow{2}{*}{$\begin{array}{l}5^{\prime}-\text { Nucleotidase } \\
(\mathrm{pmol} / \mathrm{min} / \mathrm{mg})\end{array}$} & \multirow{2}{*}{$\begin{array}{l}\text { Acid phosphatase } \\
\text { (nmol/min } / \mathrm{mg} \text { ) }\end{array}$} & \multirow{2}{*}{$\begin{array}{l}\text { Cytochrome c oxidase } \\
(\mathrm{nmol} / \mathrm{min} / \mathrm{mg})\end{array}$} & \multicolumn{2}{|c|}{$\begin{array}{l}\text { Relative specific } \\
\text { activity }\left(\times 10^{3}\right)\end{array}$} \\
\hline & & & & & PM/Lyso & PM/Mito \\
\hline $\mathrm{P}_{\mathrm{S} 1}$ & $105 \quad(100)$ & $457(100)$ & $80.0(100)$ & $76.3(100)$ & 5.7 & 6.0 \\
\hline 0.35 м/0.75 м & $43.3(41.2)$ & $365(32.8)$ & $41.8(21.5)$ & $22.4(12.1)$ & 8.7 & 16.3 \\
\hline $0.75 \mathrm{M} / \mathrm{S} 1$ & $4.8(4.5)$ & $467(4.6)$ & $60.6(3.4)$ & not detectable & 7.7 & - \\
\hline S1 layer & $13.0(12.4)$ & $469(12.7)$ & $95.4(14.8)$ & $13.1(2.1)$ & 4.9 & 35.8 \\
\hline $\mathrm{S} 1 / 1.1 \mathrm{M}$ & $7.3(6.9)$ & $414(6.2)$ & $124 \quad(10.7)$ & $21.9(2.0)$ & 3.3 & 18.9 \\
\hline $1.1 \mathrm{M} / 1.5 \mathrm{M}$ & $40.0(38.1)$ & $269(22.3)$ & $63.3(30.1)$ & 117 & 4.2 & 2.3 \\
\hline Recovery & $(103)$ & $(78.6)$ & $(80.5)$ & $(74.7)$ & & \\
\hline
\end{tabular}


$\mathrm{M} / 1.1 \mathrm{M}$ interface and was well separated from the cytochrome c oxidase peak at the $1.1 \mathrm{M} / 1.5 \mathrm{~m}$ interface. Although 5 -nucleotidase was spread across much of the gradient, a comparison of the specific activity of this enzyme to that of acid phosphatase (column 4) indicated that the $0.35 \mathrm{~m} / 0.75 \mathrm{M}$ interface had the highest relative enrichment of plasma membranes with respect to lysosomes, with a ratio of 8.7. This represented a further purification of 2.4-fold compared with the plasma membraneto-lysosome ratio of 3.7 in P3 from the 2-step gradient (calculated from Table 1). The enrichment of plasma membranes with respect to mitochondria (column 5), 16.3, was also high at the $0.35 \mathrm{M} / 0.75 \mathrm{M}$ interface. This enrichment represented a 3.5 -fold increase over that of $\mathrm{P} 3$ (calculated from Table 1).

An interesting observation was a second peak of cytochrome c oxidase activity at the $0.35 \mathrm{~m} / 0.75 \mathrm{~m}$ interface. This subpopulation of mitochondria moved upwards in the gradient (refer to the position of $\mathrm{S} 1$ in Fig. 1), in a direction opposite to that expected for that dense, protein-rich organelle. This peak probably represents activity from mitochondria that are enclosed within synaptosomes (see Fig. 5A).

\section{Morphological characterization of the gradient fractions}

We analyzed the composition of the subcellular fractions by electron microscopy. The particulate fractions from the 2-step gradient were easily distinguished by their major constituents: P3, synaptosomes; P2, synaptosomes and mitochondria; P1, chromatin and connective tissue.

Quantitative comparison of the membrane pellets by point counting (Williams, 1977) revealed that P3 contained $26 \%$ synaptosomes by volume and was enriched 5-fold with respect to the homogenate (Table 3). This degree of purity is quite similar to that found with preparations from vertebrate brain (Bradford, 1986). The corresponding values for $P 2$ were $6.9 \%$ and 1.4 -fold. The yields of synaptosomes in P2 and P3 were roughly comparable because of the greater protein content of P2 (Table 1).

The morphology of areas of synaptic vesicles (both clear and dense-core) enclosed by a circular plasma membrane profile is shown in Figure $2 A$. In a sampling of 10 fields, the diameter of the synaptosomal profile was $1.3 \pm 0.2 \mu \mathrm{m}(n=10)$ in P3 Synaptosomes often enclosed mitochondria. Their size and content of other organelles were similar to those of synaptic terminals in intact Aplysia nerve cells (Coggeshall, 1967; Tremblay et al., 1979; Schwartz and Shkolnik, 1981).

We also frequently observed synaptosomes in contact with postsynaptic elements at active zones (Fig. 2, $B, C$ ). The postsynaptic membrane was separated from the synaptosome by a well-defined gap of 20-30 nm. On the cytoplasmic sidc of the synaptosomal membrane, pyramidal electron-dense projections and adjacent electron-lucent vesicles with diameters of 50-80 $\mathrm{nm}$ were present at the site of apposition. Postsynaptic densities usually were not seen, although electron-dense material was sometimes present in the synaptic cleft. These characteristic membrane specializations have been previously described in intact Aplysia ganglia (Coggeshall, 1967; Tremblay et al., 1979; Bailey et al., 1981; Schwartz and Shkolnik, 1981).

Another neuronal structure found in $\mathbf{P} 3$ was an area of closely packed, irregular membrane profiles containing relatively few vesicles (Fig. $2 D$ ). Their organized and oriented arrangement is similar in appearance to that of neurites in the neuropil region of Aplysia ganglia. Since these areas were rare, it appeared that manual homogenization of intact ganglia adequately disrupts the neuronal components.
The membrane structures in $\mathbf{P} 2$ were usually smaller than those in P3, with an average diameter of $0.1-0.3 \mu \mathrm{m}$. Synaptosomes were present, though less numerous, and more lysosomes and free mitochondria were observed (Fig. $3 A$ ). Other neuronal structures, such as fragmented neuropil and active zones, were rare. The quantity of free $(100-200 \mathrm{~nm})$ vesicles, however, was greatly increased in P2 as compared with P3. Presumably some of these were formed during homogenization from plasma membrane and endoplasmic reticulum and some are synaptic vesicles. The P2 pellet was quite heterogeneous. Small vesicles were predominant towards the upper surface of the pellet; synaptosomes and connective tissue components, which are larger, were found in the middle and towards the bottom.

Glial cells were identified by their $5-10 \mu \mathrm{m}$ cell diameter and characteristic heterochromatin (Fig. 3B) (Schwartz and Shkolnik, 1981; Goldstein et al., 1982). They were found in both P3 and $\mathbf{P} 2$, but the yield of intact glial cells was low.

Mitochondria enclosed by intact plasma membrane profiles, such as those in synaptosomes, invariably were better preserved than free mitochondria (Fig. $3 C$ ). The organelles in sealed synaptosomes are protected from changes in ionic strength and in $\mathrm{Ca}^{2+}$ concentration. In preliminary experiments using a $0.8 \mathrm{M}$ sucrose homogenization buffer, the mitochondria appeared swollen, and the synaptosomal areas were incompletely encircled by membrane. These indications of exposure to $\mathrm{Ca}^{2+}$ were much less frequent in preparations using the $1.1 \mathrm{~m}$ sucrose buffer.

The low-speed pellet, PI, contained connective tissue components, collagen fibrils, a ribbonlike amorphous ground matrix, and a chromatin network of fine strands and electrondense particles (Coggeshall, 1967) (Fig. 4). Few intact neuronal nuclei were observed. The $\mathrm{P} 1$ pellet also appeared heterogeneous from top to bottom. Connective tissue and chromatin occupied almost the entire field, with small numbers of synaptosomes, lysosomes, and mitochondria dispersed in the upper part of the pellet.

The distributions of mitochondria and lysosomes in the 2-step gradient determined by point counting (Table 3 ) were in good agreement with those of the marker enzymes, cytochrome $c$ oxidase and acid phosphatase. By quantitative morphometry, P2 was enriched in mitochondria as compared with the homogenate, while all 3 pellets contained about the same proportion of lysosomes. This same pattern had been observed for the enzyme specific activities (Table 1).

A survey of the interface fractions of the 5-step gradient indicated that the pellet from the $0.35 \mathrm{~m} / 0.75 \mathrm{M}$ interface (Fig. $5 A$ ) was highly enriched in synaptosomes. Point counting analysis revealed an average synaptosome content of $31 \%$, with some areas as high as $60 \%$. Virtually all of the mitochondria in this fraction were sequestered within synaptosomes, and there were relatively few lysosomes. On the other hand, lysosomes were more enriched at the $0.9 \mathrm{M} / 1.1 \mathrm{M}$ interface (Fig. $5 B$ ) than in any other fraction. A similar enrichment was observed for free mitochondria at the $1.1 \mathrm{~m} / 1.5 \mathrm{~m}$ interface (Fig. $5 \mathrm{C}$ ). Thus, the morphological survey of the 5 -step gradient was also in agreement with the distribution of membranes as determined by assays of marker enzymes (Table 2).

\section{Protein kinases}

The synaptosomal fraction, $\mathrm{P} 3$, and the mixed membrane fraction, $\mathrm{P} 2$, were enriched in cAMP-dependent protein kinase ac- 

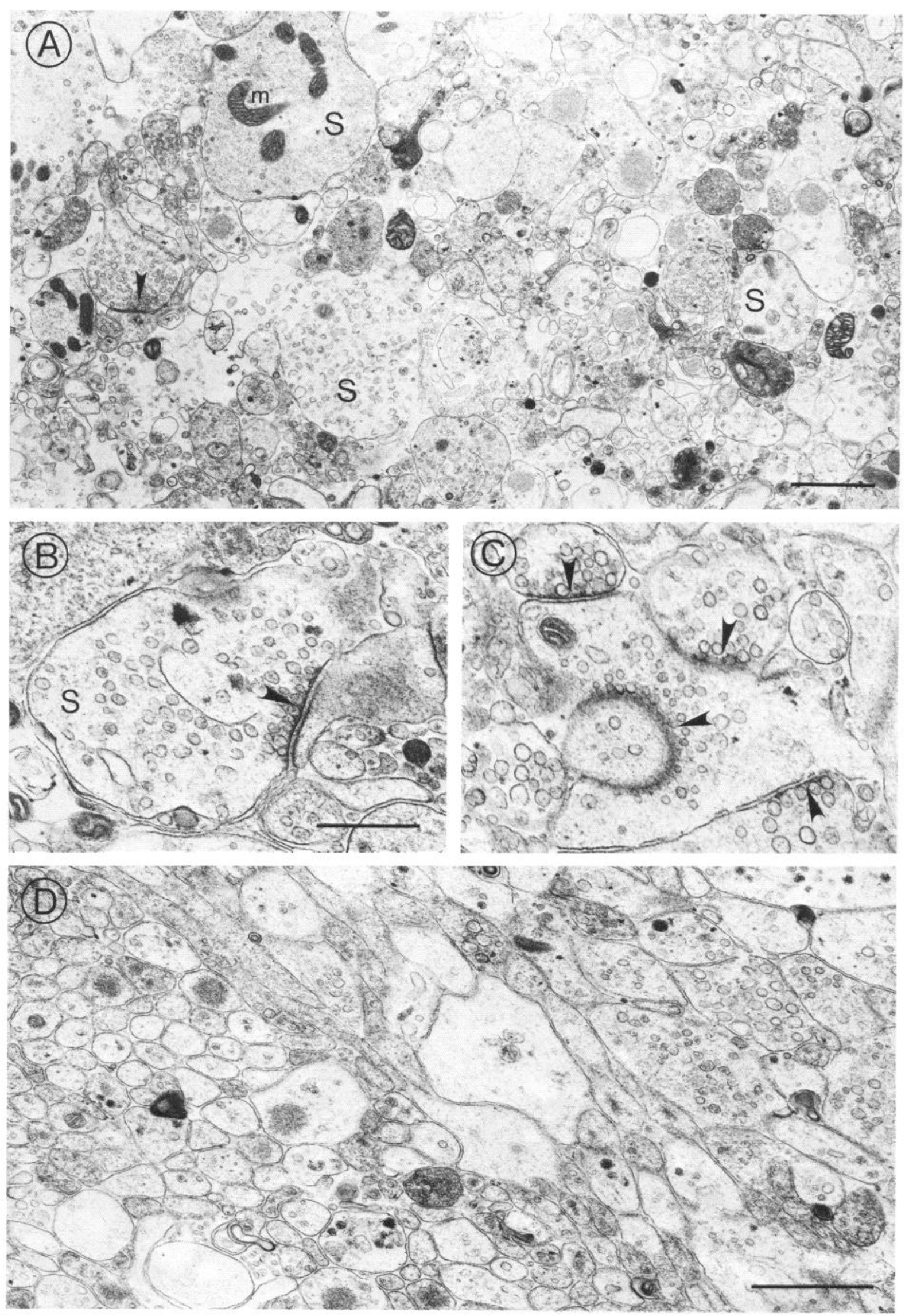

Figure 2. Neuronal structures in the synaptosome fraction, P3. A, Representative field of P3. Areas of synaptic vesicles, often including mitochondria $(m)$, enclosed by plasma membrane form synaptosomes $(S)$. Active zone indicated by arrowhead. Scale bar, $1 \mu \mathrm{m}$. $B$ and $C$, Higher magnification 


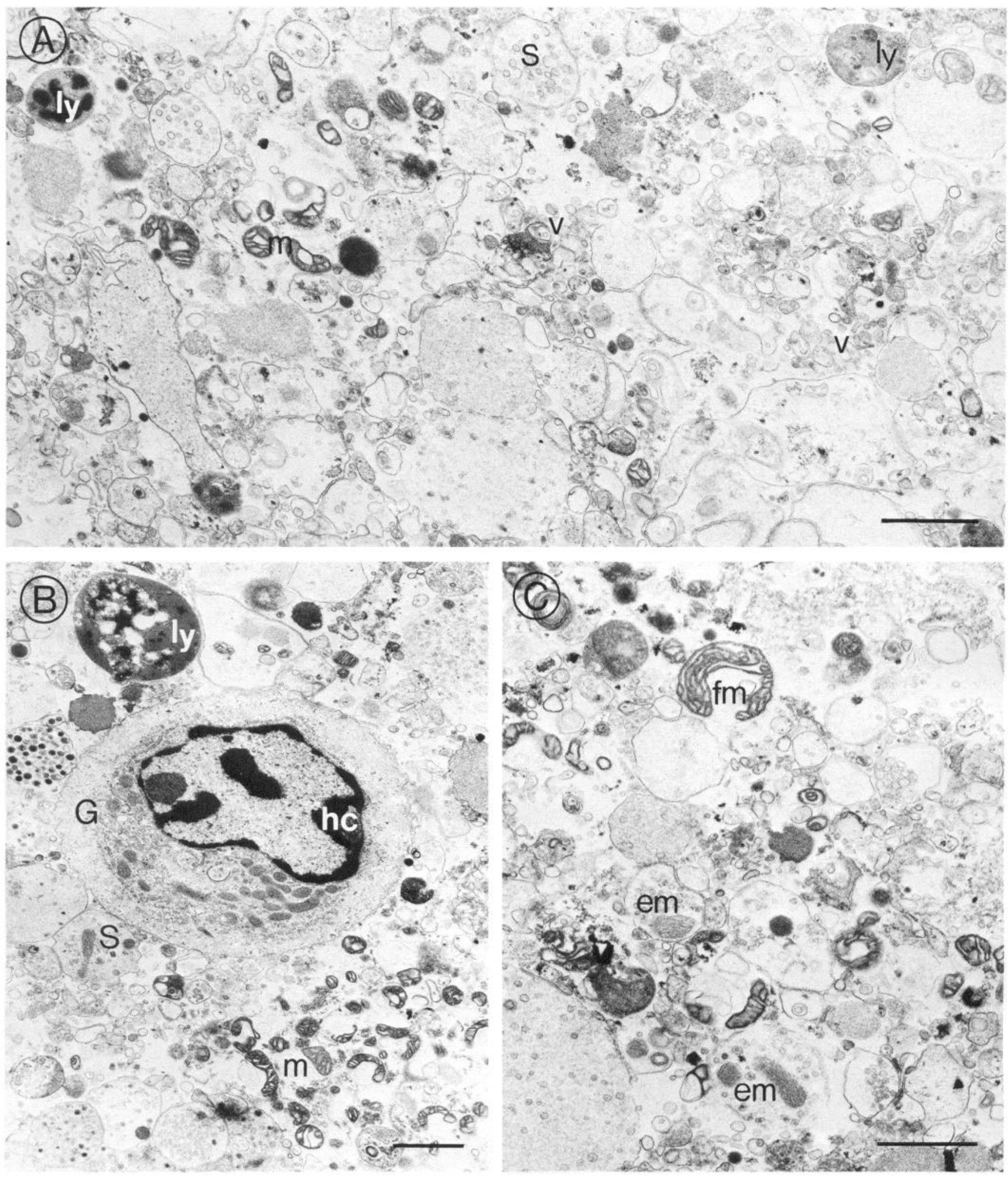

Figure 3. Neuronal components of the mixed membrane fraction, P2. A, Representative field of P2. P2 contains synaptosomes, lysosomes (ly), and mitochondria. Note the abundance of vesicles $(v)$ not enclosed by membrane. $B$, Glial cell $(G)$, showing the characteristic distribution of heterochromatin $(h c)$ beneath the nuclear membrane. $C$, Comparison of free $(\mathrm{fm})$ and enclosed $(\mathrm{em})$ mitochondria. Note the swollen cristae of the free mitochondria. All scale bars, $1 \mu \mathrm{m}$.

of several active zones revealing characteristic membrane specializations. The arrangement shown in $C$ is reminiscent of the glomerular varicosities of the modulatory histaminergic neuron, C2, of the cerebral ganglion (see Fig. $5 B$ of Schwartz et al., 1986). Scale bar, $0.5 \mu \mathrm{m}$. $D$, An area of organized neurites in both transverse and longitudinal section, resembling the neuropil region of intact ganglia. Scale bar, $1 \mu \mathrm{m}$. 


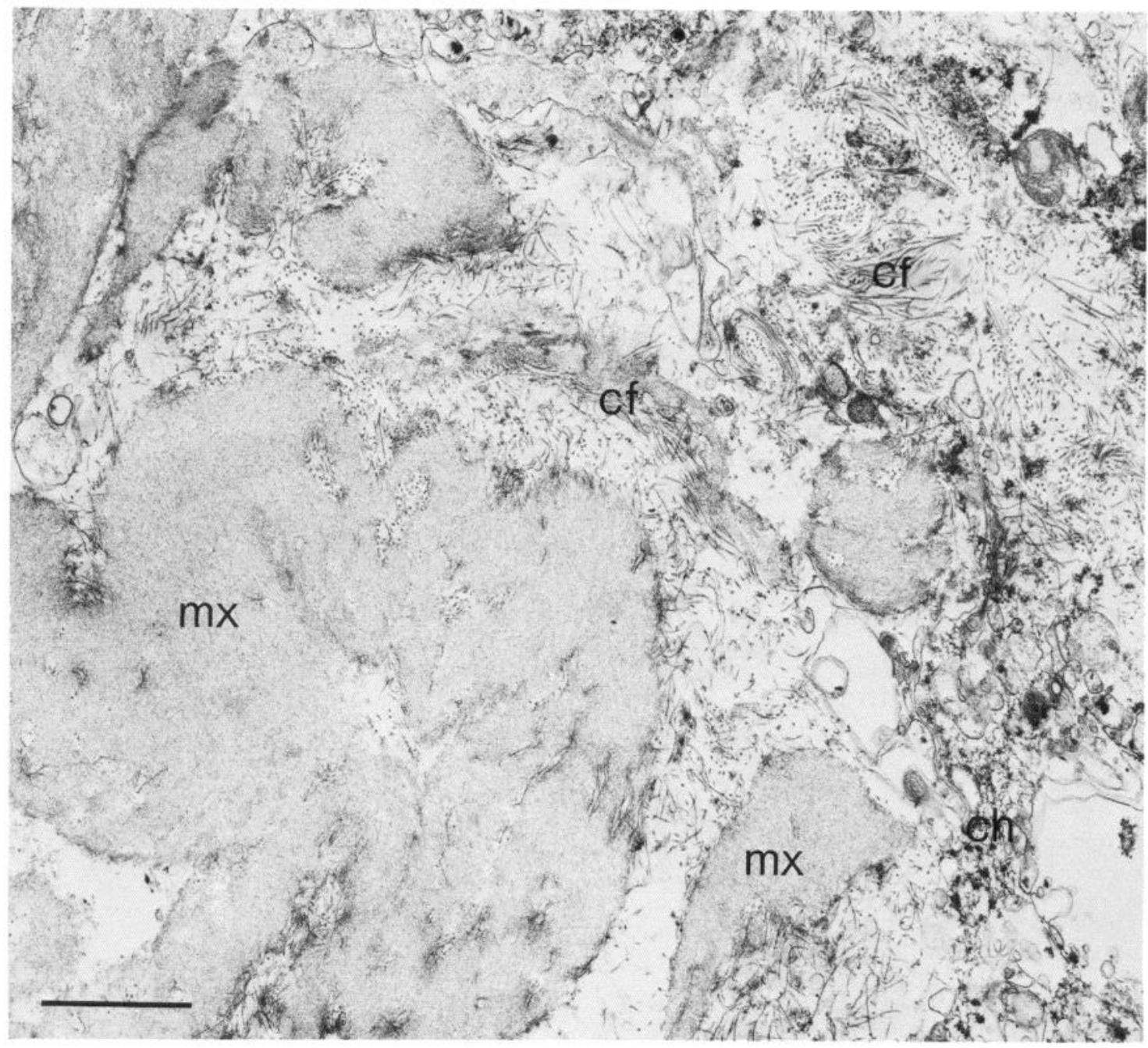

Figure 4. Structural and nuclear components of the low-speed pellet, P1. Representative field of P1. P1 contains sheath components, collagen fibers $(c f)$ and an amorphous, ground matrix $(m x)$, and chromatin $(c h)$. Scale bar, $1 \mu \mathrm{m}$.

tivity compared with the homogenate (Table 4, column 1). Enrichment of regulatory (cAMP-binding) subunits in Aplysia synaptosomes (Eppler et al., 1986; Greenberg et al., 1987a) and in synaptic fractions from rat brain (Maeno et al., 1971; Kelly et al., 1979) has been reported earlier.

The P3 and P2 fractions were also enriched in calmodulindependent protein kinase activity as compared to the homogenate (Table 4, column 2). In a survey of the substrate specificity of the Aplysia kinase, 3 histone preparations (Sigma types IIA, IIIS, VIIIS) were found to be relatively poor acceptors of phosphate (data not shown), as has been reported for rat brain and Torpedo electric organ calmodulin-dependent protein kinases (Kennedy et al., 1983; McGuinness et al., 1983; Palfrey et al., 1983). We found that a synthetic smooth muscle (chicken gizzard) myosin light chain peptide is a good substrate for the Aplysia kinase with specific activities comparable to those found by DeRiemer et al. (1984) for an Aplysia nervous tissue ho- mogenate using whole turkey gizzard myosin light chain as substrate. These results support the idea that this kinase (DeRiemer et al., 1984; Saitoh and Schwartz, 1985) is similar to the $\mathrm{Ca}^{2+}$ / calmodulin-dependent protein kinase II of rat brain (Nairn et al., 1985).

The supernatants, S2 and S3, were enriched in protein kinase C activity as compared with the homogenate (Table 4 , column 3). Measurement of protein kinase $\mathrm{C}$ activity in the subcellular fractions was complicated because detergent inhibited the Aplysia enzyme. Neither cAMP-dependent nor calmodulin-dependent protein kinase was inhibited by $0.1 \%$ NP- 40 . Furthermore, as described in the next section, this concentration of NP-40 was sufficient to render the interior of the synaptosome accessible to the external solution. In trials of protein kinase $\mathrm{C}$ assays in this work, $0.02-0.1 \%$ NP-40 or Triton X-100 at low or high protein concentrations (Kikkawa et al., 1982) gave at most $40 \%$ stimulation and usually resulted in inhibition of phosphoryla-

Figure 5. Synaptosomes, lysosomes, and mitochondria in the 5-step sucrose gradient. Selected fields. $A$, The $0.35 \mathrm{~m} / 0.75 \mathrm{~m}$ interface contains numerous synaptosomes with few lysosomes or free mitochondria. $B$, The $0.9 \mathrm{M} / 1.1 \mathrm{M}$ interface contains many organelles consisting of a single membrane enclosing fine, granular material characteristic of lysosomes. $C$, Free mitochondria at the $1.1 \mathrm{~m} / 1.5 \mathrm{~m}$ interface. Scale bar, $1 \mu \mathrm{m}$. 


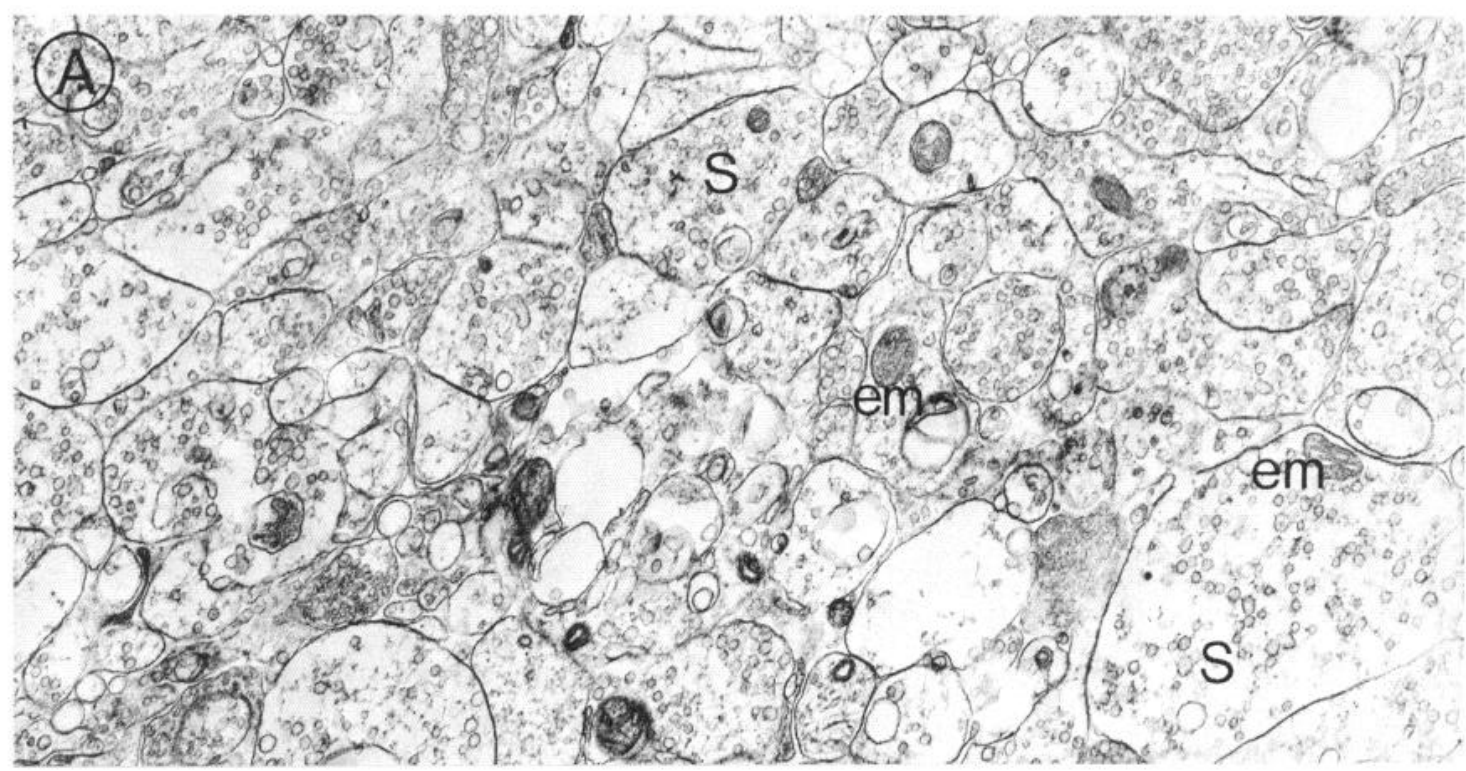

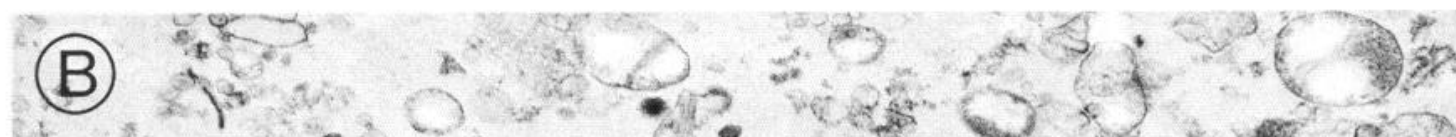

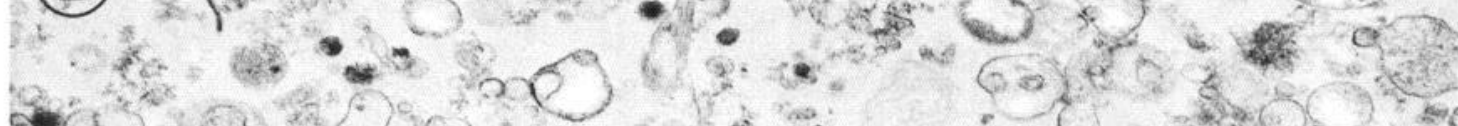
- o e e t a

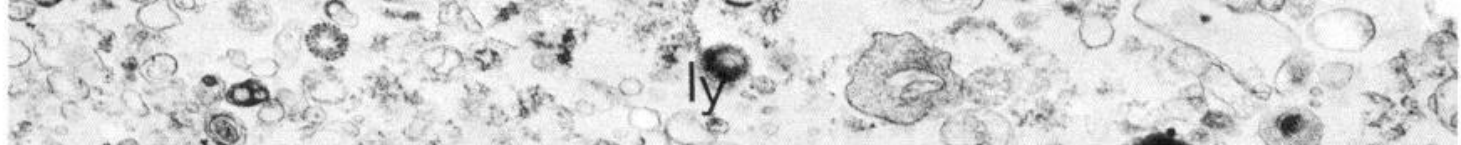

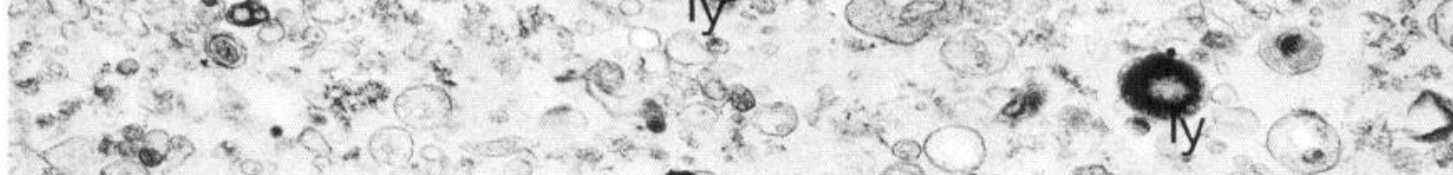

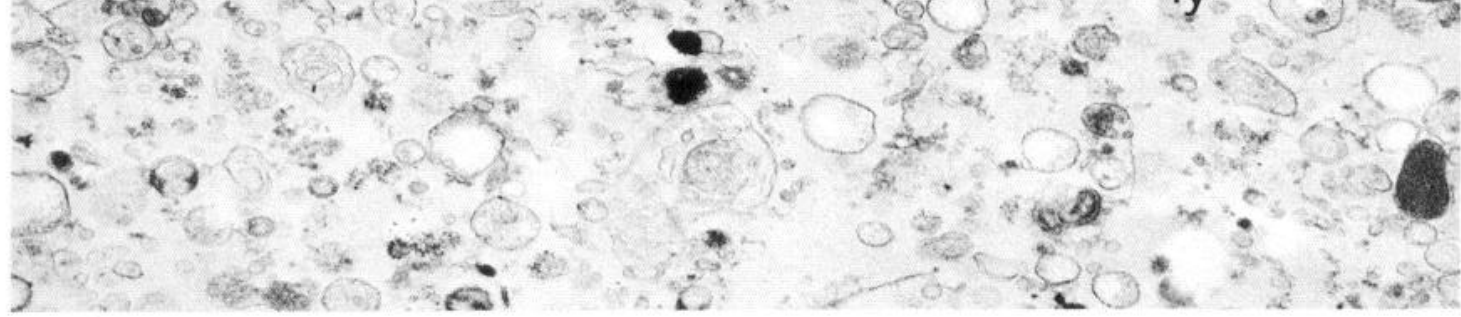
(c) 18.00 .

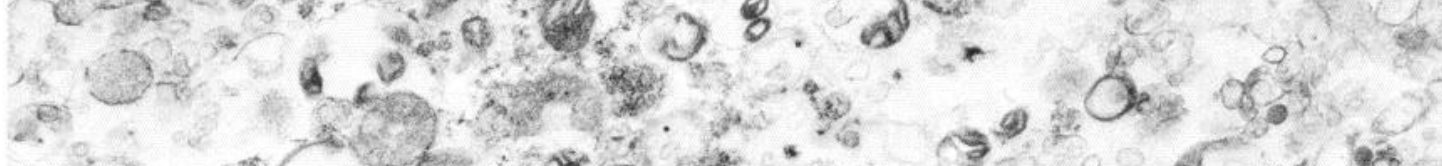

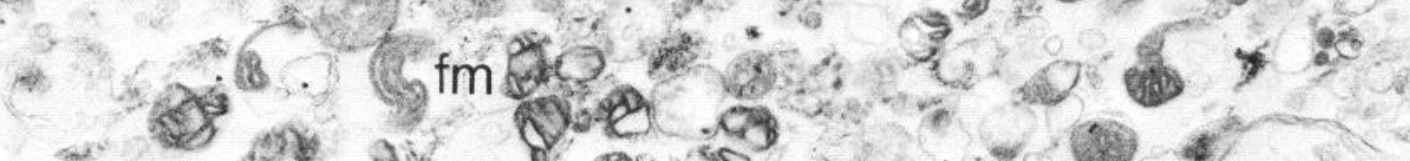

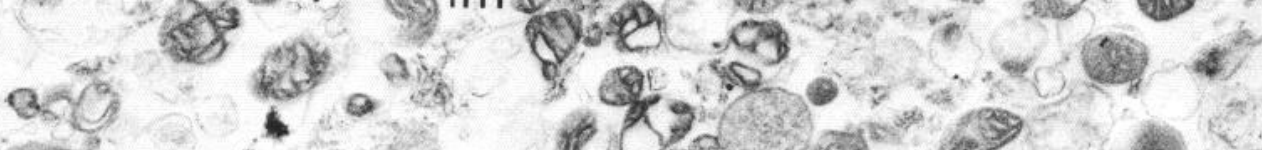

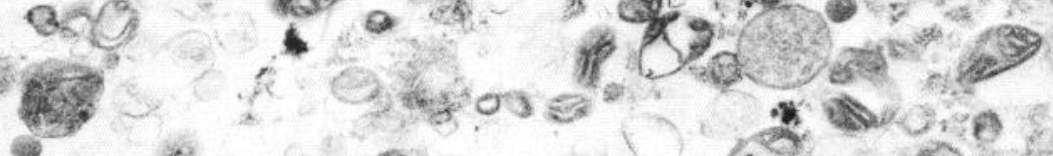

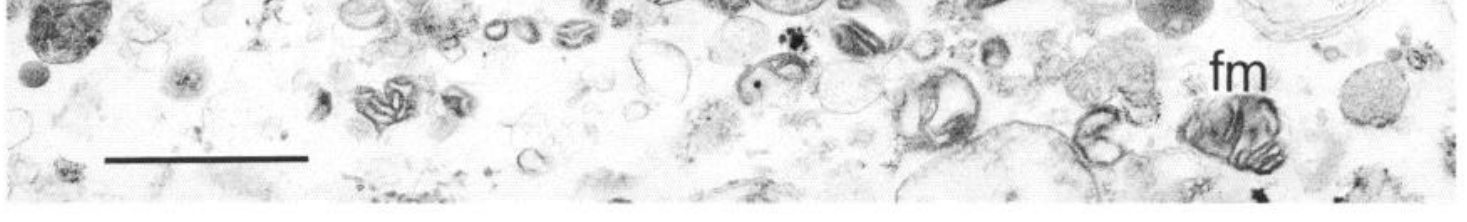




\begin{tabular}{|c|c|c|c|c|}
\hline \multirow[b]{2}{*}{$\begin{array}{l}\text { Frac- } \\
\text { tion }\end{array}$} & \multicolumn{4}{|c|}{ Percent of total points } \\
\hline & Synaptosomes & Lysosomes & $\begin{array}{l}\text { Mito- } \\
\text { chondria }\end{array}$ & $\begin{array}{l}\text { Other } \\
\text { mem- } \\
\text { brane }\end{array}$ \\
\hline $\mathrm{H}$ & $5.0 \pm 0.4$ & 1.7 & 2.0 & 91.3 \\
\hline P1 & $3.0 \pm 0.3$ & 1.4 & 1.7 & 93.9 \\
\hline $\mathrm{P} 2$ & $6.9 \pm 0.4$ & 1.7 & 3.0 & 88.4 \\
\hline P3 & $26.0 \pm 0.7$ & 1.3 & 1.8 & 70.9 \\
\hline
\end{tabular}

Fractions were prepared and analyzed by electron microscopy and point counting as described in Materials and Methods. The relative standard error (Williams, 1977) of the synaptosomal content is given.

tion. In the absence of detergent, we took the measured specific activities in the gradient fractions to be lower limits.

Although the recoveries of all 3 kinase activities are high, the distributions should still be interpreted with caution because all of these subcellular fractions are impure. The rates of reaction as well as substrate specificities could be influenced by proteolysis, phosphatases, endogenous inhibitors, etc. Further purification of the kinases from these fractions (e.g., P3-synaptosomal) would make it possible to define their functional parameters more accurately.

\section{Pertussis toxin- $G_{i / o}$}

All of the subcellular fractions from the 2-step gradient contained a $M_{r} 40,000$ pertussis toxin substrate that was resolved as a single band by SDS-PAGE (Fig. 6). The presence of both $\mathrm{G}_{\mathrm{i}}$ and $\mathrm{G}_{\mathrm{o}}$ in Aplysia nervous tissue is probable but not established (see Vogel et al., 1989, for discussion). Therefore, we refer to the $M_{r} 40,000$ pertussis substrate as $\mathrm{G}_{\mathrm{i} / \mathrm{o}}$ (Critz et al., 1986; Vogel et al., 1989). In the absence of detergent, decreasing ionic strength stimulated incorporation of radioactivity (Fig. $6 B$ ). This was due to changes in accessibility because the addition of $0.1 \%$ NP-40 eliminated any effect of ionic strength and greatly stimulated net incorporation (Fig. 6A). In a comparison of detergents, using the total homogenate, NP-40 or Lubrol PX increased ADP-ribosylation of $\mathrm{G}_{\mathrm{i} / \mathrm{o}}$ to the same extent, this effect saturating at $0.1 \%$ (data not shown). Brij 35 and saponin did not stimulate incorporation to more than $10 \%$ of maximum and were inhibitory at concentrations greater than $0.02 \%$.

Quantitation of ${ }^{32} \mathrm{P}-\mathrm{ADP}$-ribosylation in the gradient fractions revealed that P3 and P2 were enriched 2- to 3-fold com-

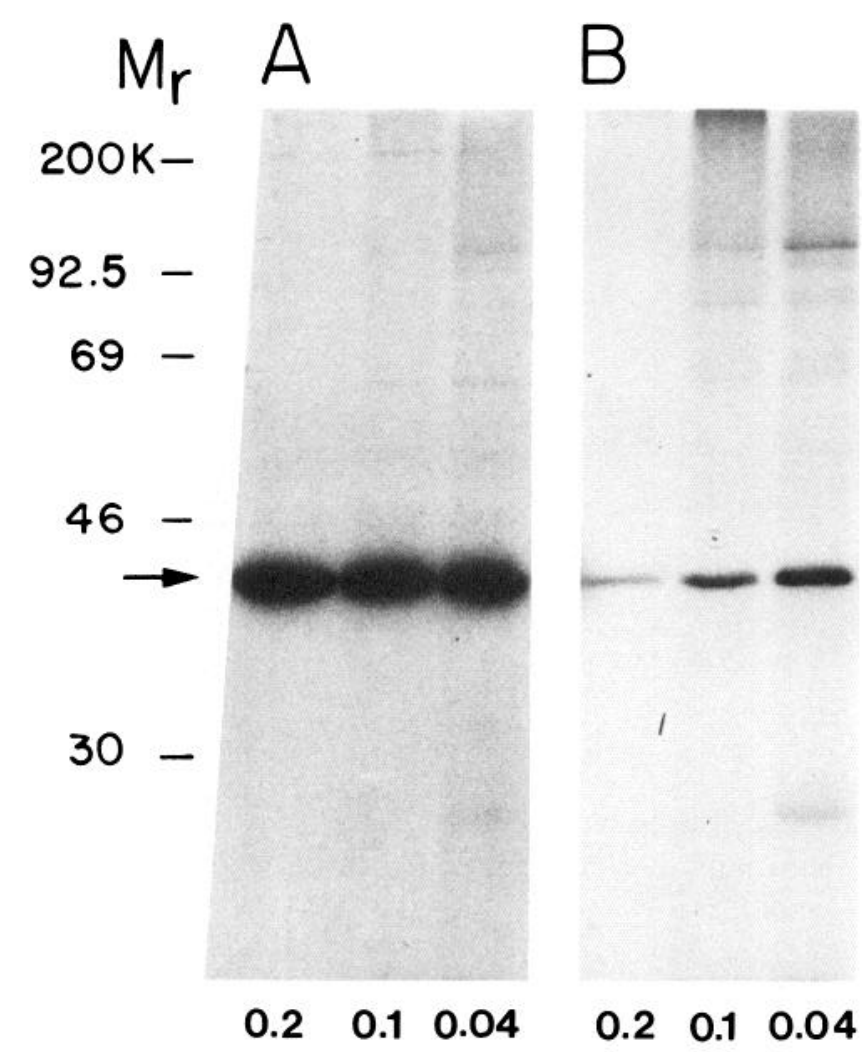

Figure 6. ADP-ribosylation of $\mathrm{G}_{\mathrm{i} / \mathrm{o}}$ in subcellular fractions of Aplysia nervous tissue. $A$, An Aplysia nervous tissue homogenate $(H)$ was incubated with ${ }^{32} \mathrm{P}-\mathrm{NAD}$ and pertussis toxin in the presence of $0.1 \% \mathrm{NP}$ 40. Samples ( $15 \mu \mathrm{g}$ protein) were analyzed by SDS-PAGE and autoradiography. The values at the bottom of each lane represent the final concentration (M) of $\mathrm{Na}^{+}$in the reaction mixture, as a result of the addition of different volumes of NSW- $\mathrm{Ca}^{2+}$. The positions of ${ }^{14} \mathrm{C}$-labeled molecular-weight marker proteins are shown at left, and the arrow points to the $M_{r} 40,000$ pertussis toxin substrate. $B$, Same as $A$ but incubated in the absence of NP-40.

pared with the homogenate (Table 5). This distribution of pertussis toxin substrate is similar to that of 5 '-nucleotidase (Table 1 , column 2), the plasma membrane marker, and is in agreement with the observation that Western blots with affinity-purified antisera specific for $\mathrm{G}_{\mathrm{o}} \alpha, \mathrm{G} \beta$, and $\mathrm{G}_{\text {common }} \alpha$ (Mumby et al., 1986) also revealed an enrichment of these proteins in P3 (Chin et al., 1987).

\begin{tabular}{|c|c|c|c|}
\hline Fraction & $\begin{array}{l}\text { cAMP-dependent } \\
\text { protein kinase }\end{array}$ & $\begin{array}{l}\mathrm{Ca}^{2+} / \text { calmodulin- } \\
\text { dependent protein kinase } \\
(\mathrm{nmol} / \mathrm{min} / \mathrm{mg})\end{array}$ & Protein kinase $\mathrm{C}$ \\
\hline $\mathrm{H}$ & $3.97 \pm 0.80(100)$ & $0.64 \pm 0.09(100)$ & $0.62 \pm 0.14(100)$ \\
\hline P1 & $3.58 \pm 0.31(36.3)$ & $0.47 \pm 0.04(24.2)$ & $0.32 \pm 0.01(20.4)$ \\
\hline P2 & $4.60 \pm 0.24(12.5)$ & $0.79 \pm 0.02(47.4)$ & $0.30 \pm 0.04(5.4)$ \\
\hline P3 & $6.39 \pm 0.33(6.0)$ & $0.95 \pm 0.07(7.1)$ & $0.43 \pm 0.06(2.6)$ \\
\hline S2 & $3.89 \pm 0.12(35.5)$ & $0.44 \pm 0.07(29.5)$ & $0.97 \pm 0.09(56.1)$ \\
\hline S3 & $3.61 \pm 0.40(7.9)$ & $0.26 \pm 0.07(3.5)$ & $0.76 \pm 0.11(10.5)$ \\
\hline Recovery & $(98)$ & $(112)$ & $(95)$ \\
\hline
\end{tabular}


Table 5. Distribution of pertussis toxin substrate in the 2-step gradient

\begin{tabular}{ll} 
Fraction & $\begin{array}{l}\text { ADP-ribosylation } \\
(\mathrm{pmol} / \mathrm{mg})\end{array}$ \\
\hline $\mathrm{H}$ & $3.2 \pm 0.2(100)$ \\
P1 & $4.5 \pm 0.0(47.6)$ \\
P2 & $7.8 \pm 0.2(26.3)$ \\
P3 & $6.9 \pm 0.3(7.2)$ \\
S2 & $1.3 \pm 0.2(15.1)$ \\
S3 & $1.5 \pm 0.9(3.8)$ \\
Recovery & $(110)$
\end{tabular}

ADP-ribosylation with pertussis toxin was measured as described in Materials and Methods. Results from 3 independent preparations are presented as $\bar{x} \pm$ SEM with percentage yields and the recovery of homogenate activity in the fractions in parentheses.

\section{Discussion}

We have prepared and characterized subcellular fractions from Aplysia that are enriched in nerve endings. These fractions also are enriched in protein kinases and $G$ proteins, components that have been implicated in modulating transmitter release. We plan to examine the endogenous substrates of the protein kinases and the enzymes regulated by $G$ proteins and to use this preparation of synaptosomes to identify other proteins that are present at Aplysia nerve terminals.

The subcellular distributions of cAMP-dependent protein kinase and protein kinase C in Aplysia nervous tissue (Table 4) are similar to those reported for rat brain (Maeno et al., 1971; Kikkawa et al., 1982). With vertebrate brain, the larger quantities of starting material allowed more purification steps to be carried out, revealing that the kinase activities, assayed in Triton $\mathrm{X}-100$, were approximately equally partitioned among fractions containing cytosol, microsomes and nuclei, and synaptosomes. Although we observed that $0.1 \%$ NP-40 permeabilized synaptosomes without inhibiting cAMP-dependent protein kinase, we were unable to unmask and preserve protein kinase $\mathrm{C}$ activity. In the rat brain synaptosome fraction, little activity was detected in the absence of detergent (Kikkawa et al., 1982). The distribution of Aplysia $\mathrm{Ca}^{2+} /$ calmodulin-dependent kinase also appears to be similar to its vertebrate counterpart. Using immunocytochemistry, Ouimet et al. (1984) found rat brain $\mathrm{Ca}^{2+}$ calmodulin-dependent protein kinase II in nerve terminals and postsynaptic densities, although the rat brain enzyme immunoreactivity was greatest in cell bodies and neurites. On the other hand, using smooth muscle myosin light chain as a substrate, Edelman et al. (1985) observed that the $\mathrm{Ca}^{2+} /$ calmodulin- $^{2}$ dependent protein kinase activity in rat brain was mainly associated with synaptosomes. We also found the highest enzyme activity in the synaptosomal fraction (Table 4). Previous work has provided evidence that $G$ proteins are associated with membranes (Sternweis and Robishaw, 1984; Vogel et al., 1989). They have been localized immunocytochemically in rat brain neuropil (Worley et al., 1986), and the presence of a $G_{s}$-like molecule (cholera toxin substrate) in Torpedo synaptosomes has been reported (Lester et al., 1982).

Our synaptosome preparation has already been used to study the role of second-messenger systems in synaptic function. The presence in the synaptosomal fraction of enzymes that metabolize arachidonic acid has been described (Piomelli et al., 1987a). Arachidonic acid metabolites have been proposed to act as sec- ond messengers in the hyperpolarizing response of Aplysia siphon sensory cells to applied FMRFamide (Piomelli et al., 1987b). Also, incubation of the synaptosomal fraction with cAMP produced changes in the ratio of catalytic to regulatory subunits of the cAMP-dependent protein kinase (Greenberg et al., 1987b). The reduction in cAMP-binding proteins has been proposed as a mechanism for long-term sensitization (Greenberg et al., 1987b). In the accompanying paper, we describe experiments demonstrating that Aplysia synaptosomes retain the ability to release transmitter, and that this release can be modulated.

\section{References}

Avruch, J., and D. F. H. Wallach (1971) Preparation and properties of plasma membrane and endoplasmic reticulum fragments from isolated rat fat cells. Biochim. Biophys. Acta 233: 334-347.

Bailey, C. H., P. Kandel, and M. Chen (1981) Active zone at Aplysia synapses: Organization of presynaptic dense projections. J. Neurophysiol. 46: 356-368

Blaustein, M. P. (1975) Effects of potassium, veratridine, and scorpion venom on calcium accumulation and transmitter release by nerve terminals in vitro. J. Physiol. (Lond.) 247: 617-655.

Bradford, H. F. (1986) Chemical Neurobiology, W. H. Freeman, New York.

Chin, G. J. (1985) Papain fragmentation of the $\left(\mathrm{Na}^{+}, \mathrm{K}^{+}\right)$-ATPase beta subunit reveals multiple membrane-bound domains. Biochemistry 24: 5943-5947.

Chin, G. J., S. S. Vogel, S. M. Mumby, and J. H. Schwartz (1987) Characterization and localization of $G_{s}$ and $G_{o}$ protein molecules in Aplysia neurons. Soc. Neurosci. Abstr. 13: 315.

Chin, G. J., E. Shapiro, and J. H. Schwartz (1989) Aplysia synaptosomes. II. Release of transmitters. J. Neurosci. 9: 49-55.

Coggeshall R. E. (1967) A light and electron microscope study of the abdominal ganglion of Aplysia californica. J. Neurophysiol. 30: 12631287.

Critz, S. D., J. F. Harper, and J. H. Byrne (1986) Evidence for the inhibitory subunits of adenylate cyclase $\left(N_{i}\right)$ in nervous and heart tissue of Aplysia. Neurosci. Lett. 64: 145-150.

DeBelleroche, J. S., and H. F. Bradford (1972) The stimulus-induced release of acetylcholine from synaptosome beds and its calcium dependence. J. Neurochem. 19: 1817-1819.

DeBelleroche, J., and H. F. Bradford (1978) Biochemical evidence for the presence of presynaptic receptors on dopaminergic nerve terminals. Brain Res. 142: 53-68.

DeRiemer, S. A., L. K. Kaczmarek, Y. Lai, T. L. McGuinness, and P. Greengard (1984) Calcium/calmodulin-dependent protein phosphorylation in the nervous system of Aplysia. J. Neurosci. 4: 16181625 .

DeRobertis, E., A. P. Delraldi, G. Rodriguez, and L. Salganicoff (1962) Cholinergic and non-cholinergic nerve endings in rat brain. J. Neurochem. 9: 22-35.

Edelman, A. M., D. D. Hunter, A. E. Hendrickson, and E. G. Krebs (1985) Subcellular distribution of calcium- and calmodulin-dependent myosin light chain phosphorylating activity in rat cerebral cortex. J. Neurosci. 5: 2609-2617.

Eisenstadt, M. L., and J. H. Schwartz (1975) Metabolism of acetylcholine in the nervous system of Aplysia californica. III. Studies of an identified cholinergic neuron. J. Gen. Physiol. 65: 293-313.

Eppler, C. M., M. J. Palazzolo, and J. H. Schwartz (1982) Characterization and localization of adenosine $3^{\prime}: 5^{\prime}$-monophosphate-binding proteins in the nervous system of Aplysia. J. Neurosci. 2: 1692-1704.

Eppler, C. M., H. Bayley, S. M. Greenberg, and J. H. Schwartz (1986) Structural studies on a family of cAMP-binding proteins in the nervous system of Aplysia. J. Cell Biol. 102: 320-331.

Gilman, A. G. (1987) G proteins: Transducers of receptor-generated signals. Annu. Rev. Biochem. 56: 615-649.

Goldstein, R. S., K. R. Weiss, and J. H. Schwartz (1982) Intraneuronal injection of horseradish peroxidase labels glial cells associated with the axons of the giant metacerebral neuron of Aplysia. J. Neurosci. 2: $1567-1577$.

Gray, E. G., and V.P. Whittaker (1962) The isolation of nerve endings from brain: An electron-microscopic study of cell fragments derived by homogenization and centrifugation. J. Anat. 96: 79-88.

Greenberg, S. M., L. Bernier, and J. H. Schwartz (1987a) Distribution 
of cAMP and cAMP-dependent protein kinases in Aplysia sensory neurons. J. Neurosci. 7: 291-301.

Greenberg, S. M., V. F. Castellucci, H. Bayley, and J. H. Schwartz (1987b) A molecular mechanism for long-term sensitization in Aplysia. Nature 329: 62-65.

Hassell, T. L., B. E. Kemp, and R. A. Masaracchia (1986) Non-muscle myosin phosphorylation sites for calcium-dependent and calciumindependent protein kinases. Biochem. Biophys. Res. Commun. 134: 240-247.

Kaczmarek, L. K., and I. B. Levitan (1987) Neuromodulation, Oxford U. P., New York.

Kandel, E. R., and J. H. Schwartz (1982) Molecular biology of learning: Modulation of transmitter release. Science 218: 433-443.

Kelly, P. T., C. W. Cotman, and M. Largen (1979) Cyclic AMPstimulated protein kinases at brain synaptic junctions. J. Biol. Chem. 254: $1564-1575$.

Kemp, B. E., R. B. Pearson, and C. House (1983) Role of basic residues in the phosphorylation of synthetic peptides by myosin light chain kinase. Proc. Natl. Acad. Sci. USA 80:7471-7475.

Kennedy, M. B., T. McGuinness, and P. Greengard (1983) A calcium/ calmodulin-dependent protein kinase from mammalian brain that phosphorylates synapsin. I. Partial purification and characterization. J. Neurosci. 3: 818-831.

Kikkawa, U., Y. Takai, R. Minakuchi, S. Ihohara, and Y. Nishizuka (1982) Calcium-activated, phospholipid-dependent protein kinase from rat brain. J. Biol. Chem. 257: 13341-13348.

Lester, H. A., M. L. Steer, and D. M. Michaelson (1982) ADP-ribosylation of membrane proteins in cholinergic nerve terminals. J. Neurochem. 38: 1080-1086.

Lowry, O. H., N. J. Rosebrough, A. L. Farr, and R. J. Randall (1951) Protein measurement with the Folin phenol reagent. J. Biol. Chem. 193: 265-275.

Maeno, H., E. M. Johnson, and P. Greengard (1971) Subcellular distribution of adenosine $3^{\prime}: 5^{\prime}$-monophosphate-dependent protein kinase in rat brain. J. Biol. Chem. 246: 134-142.

McGuinness, T. L., Y. Lai, P. Greengard, J. R. Woodgert, and P. Cohen (1983) A multifunctional calmodulin-dependent protein kinase. FEBS Lett. 163: 329-334.

Mumby, S. M., R. A. Kahn, D. R. Manning, and A. G. Gilman (1986) Antisera of designed specificity for subunits of guanine nucleotidebinding regulatory proteins. Proc. Natl. Acad. Sci. USA 83: 265-269.

Nairn, A. C., H. C. Hemmings, and P. Greengard (1985) Protein kinases in the brain. Annu. Rev. Biochem. 54:931-970.

Nichols, R. A., J. W. Haycock, J. K. T. Wang, and P. Greengard (1987) Phorbol ester enhancement of neurotransmitter release from rat brain synaptosomes. J. Neurochem. 48: 615-621.

Ouimet, C. C., T. L. McGuinness, and P. Greengard (1984) Immunocytochemical localization of calcium/calmodulin-dependent protein kinase II in rat brain. Proc. Natl. Acad. Sci. USA 81: 5604-5608.

Palfrey, H. C., J. E. Rothlein, and P. Greengard (1983) Calmodulindependent protein kinase and associated substrates in Torpedo electric organ. J. Biol. Chem. 258: 9496-9503.
Piomelli, D., E. Shapiro, S. J. Feinmark, and J. H. Schwartz (1987a) Metabolites of arachidonic acid in the nervous system of Aplysia: Possible mediators of synaptic modulation. J. Neurosci. 7: 36753686.

Piomelli, D., A. Volterra, S. A. Siegelbaum, E. R. Kandel, J. H. Schwartz, and F. Belardetti (1987b) Lipoxygenase metabolites of arachidonic acid as second messengers for presynaptic inhibition of Aplysia sensory cells. Nature 328: $38-43$.

Pollard, H. B., and G. D. Pappas (1979) Veratridine-activated release of adenosine-5'-triphosphate from synaptosomes: Evidence for calcium dependence and blockade by tetrodotoxin. Biochem. Biophys. Res. Commun. 88: 1315-1321.

Roskoski, R. (1983) Assays of protein kinase. Methods Enzymol. 99: 3-6.

Sacktor, T. C., C. A. O'Brien, I. B. Weinstein, and J. H. Schwartz (1986) Translocation from cytosol to membrane of protein kinase $\mathrm{C}$ after stimulation of Aplysia neurons with serotonin. Soc. Neurosci. Abstr. 12: 1340.

Saitoh, T., and J. H. Schwartz (1985) Phosphorylation-dependent subcellular translocation of a $\mathrm{Ca}^{2+} /$ calmodulin-dependent protein kinase produces an autonomous enzyme in Aplysia neurons. J. Cell Biol. 100: 835-842.

Schwartz, J. H., and L. J. Shkolnik (1981) The giant serotonergic neuron of Aplysia: A multi-targeted nerve cell. J. Neurosci. $I: 606-$ 619.

Schwartz, J. H., and M. E. Swanson (1987) Dissection of tissucs for characterizing nucleic acids from Aplysia: Isolation of the structural gene encoding calmodulin. Methods Enzymol. 139: 277-290.

Schwartz, J. H., A. Elste, E. Shapiro, and H. Gotoh (1986) Biochemical and morphological correlates of transmitter type in $\mathrm{C2}$, an identified histaminergic neuron in Aplysia. J. Comp. Neurol. 245: 401-421.

Sternweis, R. C., and J. D. Robishaw (1984) Isolation of two proteins with high affinity for guanine nucleotides from membranes of bovine brain. J. Biol. Chem. 259: 13806-13813.

Thompson, E. B., J. H. Schwartz, and E. R. Kandel (1976) A radioautographic analysis in the light and electron microscope of identified Aplysia neurons and their processes after intrasomatic injection of L-[ $\left.{ }^{3} \mathrm{H}\right]$ fucose. Brain Res. 112: 251-281.

Tremblay, J. P., M. Colonnier, and H. McLennan (1979) An electron microscopic study of synaptic contacts in the abdominal ganglion of Aplysia californica. J. Comp. Neurol. 188: 367-389.

Vogel, S. S., G. J. Chin, S. M. Mumby, M. Schonberg, and J. H. Schwartz (1989) G proteins in Aplysia: Biochemical characterization and regional and subcellular distribution. Brain Res. (in press).

Williams, M. A. (1977) Quantitative Methods in Biology, pp. 5-80. North-Holland, Amsterdam.

Worley, P. F., J. M. Baraban, C. van Dop, E. J. Neer, and S. H. Snyder (1986) $\mathrm{G}_{o}$, a guanine nucleotide-binding protein: Immunohistochemical localization in rat brain resembles distribution of second messenger systems. Proc. Natl. Acad. Sci. USA 83: 4561-4565. 